OPEN ACCESS

Edited by:

Robert Czajkowski,

University of Gdańsk, Poland

Reviewed by:

Taha Menasria,

University of Tébessa, Algeria

Mehrdad Moosazadeh Moghaddam

Baqiyatallah University of Medical Sciences, Iran

*Correspondence: Tanim J. Hossain tanim.bmb@gmail.com

Specialty section: This article was submitted to

Microbial Symbioses,

a section of the journal

Frontiers in Microbiology

Received: 18 June 2020 Accepted: 10 August 2020 Published: 26 August 2020

Citation:

Hossain TJ, Chowdhury SI, Mozumder HA, Chowdhury MNA, Ali F, Rahman N and Dey S (2020) Hydrolytic Exoenzymes Produced by Bacteria Isolated and Identified From the Gastrointestinal Tract of Bombay

Duck. Front. Microbiol. 11:2097.

doi: 10.3389/fmicb.2020.02097

\section{Hydrolytic Exoenzymes Produced by Bacteria Isolated and Identified From the Gastrointestinal Tract of Bombay Duck}

\author{
Tanim J. Hossain ${ }^{1 *}$, Sumaiya I. Chowdhury ${ }^{1}$, Halima A. Mozumder', \\ Mohammad N. A. Chowdhury', Ferdausi Ali ${ }^{2}$, Nabila Rahman ${ }^{3}$ and Sujan Dey ${ }^{2}$
}

'Department of Biochemistry and Molecular Biology, University of Chittagong, Chattogram, Bangladesh, ${ }^{2}$ Department of Microbiology, University of Chittagong, Chattogram, Bangladesh, ${ }^{3}$ Department of Biology, Chittagong Sunshine College, Chattogram, Bangladesh

Bacteria producing hydrolytic exoenzymes are of great importance considering their contribution to the host metabolism as well as for their various applications in industrial bioprocesses. In this work hydrolytic capacity of bacteria isolated from the gastrointestinal tract of Bombay duck (Harpadon nehereus) was analyzed and the enzyme-producing bacteria were genetically characterized. A total of twenty gutassociated bacteria, classified into seventeen different species, were isolated and screened for the production of protease, lipase, pectinase, cellulase and amylase enzymes. It was found that thirteen of the isolates could produce at least one of these hydrolytic enzymes among which protease was the most common enzyme detected in ten isolates; lipase in nine, pectinase in four, and cellulase and amylase in one isolate each. This enzymatic array strongly correlated to the previously reported eating behavior of Bombay duck. 16S rRNA gene sequence-based taxonomic classification of the enzyme-producing isolates revealed that the thirteen isolates were grouped into three different classes of bacteria consisting of eight different genera. Staphylococcus, representing $\sim 46 \%$ of the isolates, was the most dominant genus. Measurement of enzyme-production via agar diffusion technique revealed that one of the isolates which belonged to the genus Exiguobacterium, secreted the highest amount of lipolytic and pectinolytic enzymes, whereas a Staphylococcus species produced highest proteolytic activity. The Exiguobacterium sp. expressing a maximum of four hydrolases, appeared to be the most promising isolate of all.

Keywords: Bombay duck, gut bacteria, extracellular hydrolytic enzyme, exoenzyme, protease, lipase, pectinase, $16 S$ rRNA gene sequence

\section{INTRODUCTION}

The gastrointestinal (GI) tract of fishes, like those of other vertebrate-hosts, harbors a complex community of bacteria that significantly influence host's physiology via metabolic interactions (Sommer and Bäckhed, 2013; Romero et al., 2014; Krishnan et al., 2015; Wang et al., 2018). Producing a diverse array of extracellular hydrolytic enzymes, the intestinal flora carry out a wide 
range of catabolic and biotransformation reactions which are distinct from, but complement the metabolic processes of the host (Krishnan et al., 2015; Banerjee and Ray, 2017; Egerton et al., 2018; Rowland et al., 2018). Several papers have already reported the purification and characterization of a number of hydrolytic exoenzymes such as protease, lipase, amylase, cellulase and chitinase, among others, from the GI bacteria of various freshwater and marine fishes (Ray et al., 2012). Some of these enzymes were found largely diversified in their enzymatic properties and substrate specificities (Sugita et al., 1996; Bairagi et al., 2002; Saha et al., 2006; Ray et al., 2007, 2012; Esakkiraj et al., 2008; Lazado et al., 2012; Ananthi et al., 2014; Kawashima et al., 2016). Fish GI bacteria therefore represent a dynamic source of hydrolytic enzymes for potential applications in many industries such as biotechnology, food, pharmaceuticals, aquaculture, detergent, paper, textiles etc. The GI bacteria of marine fishes are of particular interest in this regard because microbial enzymes from marine environment are renowned for their extraordinary chemical and metabolic abilities (Debashish et al., 2005; Sarkar et al., 2010; Zhang and Kim, 2010). Being the largest ecosystem on earth, the marine environment constitutes one of the richest reserves of bacteria, majority of which remain entirely unexplored and unexploited (Das et al., 2006; Penesyan et al., 2010; Finore et al., 2014). This massive bacterial population is considered as a potent source of novel enzymes and many other bioactive compounds (Newman and Hill, 2006; Lee et al., 2010; Rao et al., 2017; Romano et al., 2017; Sivaperumal et al., 2017). Besides, compared to the enzymes of terrestrial origin, the marine-derived bacterial enzymes, through millions years of evolution, acquired additional characteristics that help the bacteria adapt to the extreme and constantly changing marine environments (de Carvalho and Fernandes, 2010; Zhang and Kim, 2010; Dash et al., 2013; Nikolaivits et al., 2017). With large catalytic activity and flexibility, the marine bacterial enzymes can work in conditions like high pressure, high salinity, high viscosity and high and low temperatures (Zhang and Kim, 2010; Trincone, 2011; Nikolaivits et al., 2017). Some of the enzymes acquire unique chemical or stereochemical properties such as substrate specificity and enantioselectivity, which can be exploited in the chemical and pharmaceutical industries (Trincone, 2010; Parte et al., 2017). Since GI tract of fishes is an open system constantly interacting with the surrounding environment, the diverse bacterial population of the marine environment, taking advantage of their uninterrupted access to the GI tract, forms a major portion of the GI microbiota of fishes (Mondal et al., 2010). Moreover, in comparison with the neighboring environment, the fish GI tract is relatively richer in nutrients and therefore offers a favorable growth environment for the bacteria (Mondal et al., 2010). Hence, studying GI bacteria of marine fishes is of great importance for the discovery of beneficial strains as a promising source of novel biocatalysts.

This work attempts to isolate and characterize extracellular hydrolase producing GI bacteria of Bombay duck (Harpadon nehereus), a brackish-water marine lizardfish which has a wide and discontinuous distribution along the coasts of China, India, Bangladesh, East Africa, Malaya and Indonesia (Bapat, 1967; Behera et al., 2015; Zhang et al., 2017). This fish is voracious, carnivorous and cannibalistic in its eating behavior (Kurian, 2000; Balli et al., 2006; Ghosh, 2014; He et al., 2018) with its diet consisted mainly of prawn, shrimp, fish, fish larva and crab (Khan et al., 1992; Balli et al., 2006; Ghosh, 2014; Zhang and Jin, 2014). Presence of plant matters has also been reported in a few studies, though in very small amounts (Mookerjee et al., 1946; Pillay, 1953; Bapat, 1970). It is known that eating habit or, the type of diet is a key factor shaping the composition of gut microbiota (Bairagi et al., 2002, p. 1; Ray et al., 2012; Senghor et al., 2018). Prevalence of protein and fat in the diet of Bombay duck, and lack of plant-derived polysaccharides such as cellulose, starch, chitin, pectin, xylan etc. indicate that the bacteria having extracellular proteolytic and lipolytic activity might predominate in its gut microbiota in comparison to those having cellulolytic, amylolytic, chitinolytic, pectinolytic, or, xylanolytic activity. Each of these hydrolytic enzymes has numerous applications in many industrial bioprocesses and therefore is of great commercial value (Uhlig, 1998; Kirk et al., 2002; Sarrouh et al., 2012; Gurung et al., 2013; Liu and Kokare, 2017). Despite the biotechnological prospects as well as its importance to the host, fundamental knowledge on the gut-associated microbiota of Bombay duck and its hydrolytic enzyme potential has still remained unexplored.

In the present study, GI bacteria of Bombay duck (hereafter referred to as BDGB) were isolated with the aim of evaluating their hydrolytic capacities for potential applications in aquaculture and biotechnology. The isolated strains were examined for the production of five different hydrolytic enzymes such as protease, lipase, pectinase, cellulase and amylase, and the enzyme-producing strains were characterized based on their $16 \mathrm{~S}$ rRNA gene sequences. This is the first report about the isolation and genetic identification of the enzyme producing gut bacteria of Bombay duck.

\section{MATERIALS AND METHODS}

\section{Preparation of Intestinal Sample}

For isolation of the GI bacteria, intestinal sample was prepared separately from two Bombay duck fishes that were purchased from a seaside fish market of Chattogram city. The two fishes were 19.7 and $20.02 \mathrm{~cm}$ in length and 85.7 and $87 \mathrm{~g}$ in weight, respectively. Entire GI tract of each fish was aseptically dissected and washed thoroughly with sterile distilled water (Bairagi et al., 2002). The intestinal contents were then squeezed out and inside of the intestine was rinsed well with water, and both were mixed together to obtain the intestinal sample.

\section{Isolation of Bacteria and Culture Conditions}

Five-fold serial dilutions of the intestinal sample were prepared in sterile distilled water and $100-\mu \mathrm{L}$ aliquot of each dilution was spread on the surface of nutrient agar (NA; $5 \mathrm{~g} / \mathrm{L}$ peptone, $3 \mathrm{~g} / \mathrm{L}$ yeast extract, $5 \mathrm{~g} / \mathrm{L} \mathrm{NaCl}, 18 \mathrm{~g} / \mathrm{L}$ agar; $\mathrm{pH} 7$ ) and Luria-Bertani (LB) agar (10 g/L tryptone, $5 \mathrm{~g} / \mathrm{L}$ yeast extract, $10 \mathrm{~g} / \mathrm{L} \mathrm{NaCl}, 18 \mathrm{~g} / \mathrm{L}$ agar; $\mathrm{pH} 7$ ). After incubation at $30^{\circ} \mathrm{C}$ for 24 to $48 \mathrm{~h}$, colonies with distinct morphological appearances were selected, restreaked and subcultured on fresh media until pure cultures were obtained 
(Hossain et al., 2011). The cultures were preserved at $-40^{\circ} \mathrm{C}$ as $20 \% \mathrm{v} / \mathrm{v}$ glycerol stocks in LB or nutrient broth. For all analyses described below, cultures were first activated by inoculating cells from the glycerol stocks in nutrient broth or LB media and after incubation overnight at $30^{\circ} \mathrm{C}, \mathrm{OD}_{600}$ of the overnight cultures was adjusted to 0.8 .

\section{Screening Isolates for Extracellular Hydrolytic Enzyme Production}

The isolated bacteria were screened for the production of protease, lipase, pectinase, cellulase and amylase enzymes in agar plate assay. Activated culture of each isolate was streaked on agar media containing suitable substrate specific for each of the enzyme activities. For example, gelatin, Tween-80, pectin, carboxymethylcellulose (CMC) and starch were used for the detection of proteolytic, lipolytic, pectinolytic, cellulolytic and amylolytic activities, respectively. After incubation at $30^{\circ} \mathrm{C}$ for $48 \mathrm{~h}$, the culture-media were treated with specific staining solutions as described below. Formation of zones of clear halo surrounding the colonies indicated presence of the respective enzymes. For the detection of proteolytic activity, the isolates were inoculated onto gelatin-agar media $(10 \mathrm{~g} / \mathrm{L}$ gelatin, $5 \mathrm{~g} / \mathrm{L}$ tryptone, $1 \mathrm{~g} / \mathrm{L}$ glucose, $2.5 \mathrm{~g} / \mathrm{L}$ yeast extract, $20 \mathrm{~g} / \mathrm{L}$ agar; $\mathrm{pH}$ 7) and incubated at $30^{\circ} \mathrm{C}$ for $48 \mathrm{~h}$ followed by staining the media with mercuric chloride solution $\left(150 \mathrm{~g} / \mathrm{L} \mathrm{HgCl}_{2}\right.$ in $20 \% \mathrm{v} / \mathrm{v} \mathrm{HCl}$ ). Development of transparent circles around the colonies indicated a positive reaction (Fry et al., 1994). Similarly for lipolytic activity, the isolates were inoculated on Tween 80-agar media (15 mL/L Tween 80, $5 \mathrm{~g} / \mathrm{L}$ tryptone, $2.5 \mathrm{~g} / \mathrm{L}$ yeast extract, $5 \mathrm{~g} / \mathrm{L} \mathrm{NaCl}, 20 \mathrm{~g} / \mathrm{L}$ agar; $\mathrm{pH} \mathrm{7)}$ and incubated at $30^{\circ} \mathrm{C}$ for $48 \mathrm{~h}$. The appearance of clear halos after staining with methyl red solution $(0.2 \mathrm{~g} / \mathrm{L}$ methyl red in $95 \%$ ethanol) indicated the presence of lipolytic activity (Samad et al., 1989). For pectinolytic activity, isolates grown on pectin-agar media ( $5 \mathrm{~g} / \mathrm{L}$ pectin, $5 \mathrm{~g} / \mathrm{L}$ tryptone, $2.5 \mathrm{~g} / \mathrm{L}$ yeast extract, $5 \mathrm{~g} / \mathrm{L} \mathrm{NaCl}, 15 \mathrm{~g} / \mathrm{L}$ agar; $\mathrm{pH}$ 7) were flooded with potassium iodide solution $(20 \mathrm{~g} / \mathrm{L}$ potassium iodide and $10 \mathrm{~g} / \mathrm{L}$ iodine) and examined for the appearance of clear zones to confirm pectinase production (Soares et al., 1999). For the determination of cellulolytic activity, the isolates were inoculated onto CMC-agar plates (10 g/L CMC, $2 \mathrm{~g} / \mathrm{L}$ tryptone, $4 \mathrm{~g} / \mathrm{L}$ $\mathrm{KH}_{2} \mathrm{PO} 4,4 \mathrm{~g} / \mathrm{L} \mathrm{Na} \mathrm{NPO}_{4}, 0.2 \mathrm{~g} / \mathrm{L} \mathrm{MgSO}_{4} .7 \mathrm{H}_{2} \mathrm{O}, 0.001 \mathrm{~g} / \mathrm{L}$ $\mathrm{CaCl}_{2}, 0.001 \mathrm{~g} / \mathrm{L} \mathrm{FeSO}_{4} .7 \mathrm{H}_{2} \mathrm{O}, 20 \mathrm{~g} / \mathrm{L}$ agar; $\mathrm{pH}$ 7). After incubation at $30^{\circ} \mathrm{C}$ for $48 \mathrm{~h}$, the plates were first stained with Congo red solution $(2 \mathrm{~g} / \mathrm{L})$ for $10 \mathrm{~min}$ and then destained with $1 \mathrm{M} \mathrm{NaCl}$ for $15 \mathrm{~min}$; halo zones surrounding the colonies indicated cellulase production (Meddeb-Mouelhi et al., 2014). For amylolytic activity, bacteria grown on starch-agar media (10 g/L soluble starch, $5 \mathrm{~g} / \mathrm{L}$ tryptone, $3 \mathrm{~g} / \mathrm{L}$ yeast extract, $20 \mathrm{~g} / \mathrm{L}$ agar; $\mathrm{pH}$ 7) were flooded with potassium iodide solution; transparent zones surrounding the colonies indicated amylase production (Amoozegar et al., 2003).

\section{Measurement of Enzyme-Production}

Amount of enzyme-production by the isolates was determined by agar diffusion method. The isolates were grown on media containing specific substrates for the respective enzymes as performed in the screening experiment described above and diameter of the zones of clearance and that of the colonies were measured. Amount of the enzyme produced was then calculated, and expressed as enzyme intensity (EI) where EI = (colony diameter + halo zone diameter)/colony diameter (Aleem et al., 2018; Ashok et al., 2019). Each experiment was performed in triplicate and averaged.

\section{S rRNA Gene Amplification and Sequencing}

To amplify 16S rRNA genes of the enzyme-producing isolates, their genomic DNA was extracted using a Maxwell 16 Blood DNA Purifcaton Kit (Promega, Madison, WI, United States) according to the manufacturer's recommendations. Nearly full length of the 16S rRNA gene was amplified from the genomic DNA by PCR using the universal primers 27F (5'-AGAGTTTGATCCTGGCTCAG-3') and 1492R (5'GGTTACCTTGTTACGACTT-3') (Miyoshi et al., 2005) in a $20-\mu \mathrm{L}$ reaction volume which contained $10 \mu \mathrm{L}$ GoTaq G2 Hot Start Master Mix (Promega), $1 \mu \mathrm{L}$ genomic DNA (25 to $65 \mathrm{ng} / \mu \mathrm{L}), 1 \mu \mathrm{L}$ of each primer (10 to $20 \mathrm{pM}$ ) and water. The PCR program consisted of an initial denaturation step at $95^{\circ} \mathrm{C}$ for $3 \mathrm{~min}$ followed by 35 rounds of temperature cycling comprising denaturation at $95^{\circ} \mathrm{C}$ for $30 \mathrm{~s}$, annealing at $48^{\circ} \mathrm{C}$ for $30 \mathrm{~s}$, and extension at $72^{\circ} \mathrm{C}$ for $90 \mathrm{~s}$, followed by a final extension at $72^{\circ} \mathrm{C}$ for $5 \mathrm{~min}$ and cooling to $4^{\circ} \mathrm{C}$. The PCR products were purified using a Wizard SV Gel and PCR CleanUp System (Promega) and subjected to sequencing with the same primers that were used for the original PCR amplification using a BigDye Terminator v3.1 Cycle Sequencing Kit (Applied Biosystems) according to the manufacturer's instructions. The sequences have been deposited in the National Center for Biotechnology Information (NCBI) Data Bank under accession numbers (ACNs) MN611242 to MN611254.

\section{Analysis of 16S rRNA Gene Sequences}

Sequence similarity of the $16 \mathrm{~S}$ rRNA genes with those in the database were performed by NCBI blastn suite (Johnson et al., 2008), EzBioCloud's 16S-based ID (database version 2019.08.06) (Yoon et al., 2017) and RDP seqmatch (Cole et al., 2014). The top-hit database strain corresponding to each isolate was selected based on the maximum score and/or number of hits they showed in the BLAST and RDP seqmatch search results. Organisms with an ambiguous description such as enrichment culture clones, uncultured or unclassified bacteria were not taken into consideration (Hossain et al., 2018). Taxonomic classification of the isolates based on the $16 \mathrm{~S}$ rRNA genes was performed using RDP classifier program (Cole et al., 2014) with the confidence threshold setting at $80 \%$.

\section{Construction of Phylogenetic Tree}

Phylogenetic tree was constructed as previously described (Hossain et al., 2018). 16S rRNA gene sequences of type-strains (T) which are closely related to the enzyme-producing isolates were retrieved from EzBioCloud database (Yoon et al., 2017). 
The retrieved sequences and sequences of the isolated strains were aligned by MUSCLE or ClustalW algorithms in Geneious Prime 2019.2.3 ${ }^{1}$. Phylogenetic tree of the aligned sequences was built using the maximum likelihood method (Aldrich, 1997) with Tamura-Nei distance algorithm in MEGA-X (Kumar et al., 2018) with 1000 bootstrap replicates. Trees were also calculated using two other algorithms such as parsimony and neighbor-joining with Jukes-Cantor correction in MEGA-X which produced same results.

\section{RESULTS}

\section{Distribution of Hydrolytic Enzyme Activities Among the Isolated Bacteria}

The objective of the present work was to investigate the production of extracellular hydrolytic enzymes by bacteria associated with the GI tract of Bombay duck. Consequently, twenty bacterial strains, based on their divergence in the colony morphology, size and color, were isolated from the GI tract of this fish. 16S rRNA gene sequence analysis (described later), however, indicated that a few of these isolates were of same species and there were, in fact, seventeen different species among the isolates. The seventeen isolates, designated as BDGB1 to BDGB17, were screened for the presence of five different hydrolytic enzyme activities viz. proteolytic, lipolytic, pectinolytic, cellulolytic and amylolytic activities (Figures 1A-E). Of those, thirteen $(\sim 77 \%)$ isolates were found expressing at least one of the five enzyme activities tested (Figure 1F). Distribution of the enzyme activities among the isolates is summarized in Table 1. Proteolytic activity was found to be the most common hydrolytic activity detected in a maximum of ten $(\sim 59 \%)$ isolates, very closely followed by the lipolytic activity detected in nine $(\sim 53 \%)$ of the isolates. Pectinolytic activity, however, was less frequently detected being produced by only four ( $\sim 24 \%)$ of the isolates whereas cellulolytic and amylolytic activity was very rare, found in one isolate each (Table 1 and Figure 1F). While none of the isolates expressed all the five hydrolytic enzymes, several of them produced two or more. A maximum of four hydrolytic enzymes were produced by only one isolate viz. BDGB17. Three different enzyme activities were detected in two of the isolates whereas two enzyme activities, which were generally protease and lipase, were detected in five isolates (Table 1). Five other isolates expressed only one hydrolytic enzyme which in most cases was either protease or lipase. The remaining four isolates, BDGB3, BDGB5, BDGB13, and BDGB14, did not show any of the enzyme activities tested.

\section{Taxonomic and Hydrolytic Diversity of the Enzyme Producing Isolates}

To explore taxonomic diversity of the enzyme-producing isolates in the GI tract of Bombay duck, sequences of their 16S rRNA genes were analyzed. The sequences of the seventeen isolates were clustered into thirteen different operational taxonomic units (OTUs) based on $>99 \%$ sequence identity. The sequence

${ }^{1}$ https://www.geneious.com homology of the isolates and the sequence-based taxonomic identity were determined and presented in Table 2. The isolated strains showed more than 99\% homology to the nearest neighboring sequences and at least $98 \%$ homology to the closest type strain sequences, supporting the taxonomic annotation to minimum genus level. The 16S rRNA gene-based phylogenetic tree illustrating evolutionary relationships among the enzyme-producing isolates, revealed that the thirteen isolates were distributed into three main clusters (Figure 2). Similarly, taxonomic classification of the isolates based on their 16S rRNA gene sequences also suggested that the isolates were grouped into three taxonomic classes including Actinobacteria, Bacilli and Gammaproteobacteria (Figure 3A) with Actinobacteria being the most diverse and Bacilli the largest. The four isolates of Actinobacteria were each affiliated to a different genus such as Corynebacterium, Kocuria, Microbacterium, and Micrococcus. On the other hand, Bacilli, accommodating a maximum of eight enzyme-producing isolates (61.5\%), was rather less diverse, represented by only three different genera including Staphylococcus (six isolates), Macrococcus (one isolate) and Exiguobacterium (one isolate). The remaining phylotype, Gammaproteobacteria, included just one genus, i.e., Shewanella (one isolate). Staphylococcus, which was represented by $\sim 46 \%$ of the enzyme-producing isolates, was the most dominant among the eight genera (Figure 3A). Interestingly, most ( $67 \%$ ) isolates belonging to Staphylococcus expressed only one of the five hydrolytic enzymes. In contrast, the rest of the genera were each consisted of a single isolate but most $(\sim 86 \%)$ of them showed multi-enzyme capacity. The proteolytic and the pectinolytic strains, however, mostly fell in the Staphylococcus group (see Supplementary Figure S1). The 16S rRNA genebased taxonomic affiliations also revealed that all of the identified isolates were Gram-positive bacteria with medium to high GCcontent (50.8 to $57.2 \%$ ), except only the Shewanella sp. which was Gram-negative.

On the other hand, analysis of enzymatic diversity in the two major taxonomic classes, Actinobacteria and Bacilli, suggested that the isolates of Bacilli were mostly proteolytic (87.5\%), whereas half of the isolates of Actinobacteria were proteolytic but all of them expressed lipolytic activities (Figure 3B). The extent of hydrolytic activity at the genus level showed that more than $80 \%$ of the Staphylococcus sp. were proteolytic but none of the six Staphylococcus isolates was found to be cellulolytic or amylolytic (Figure 3C).

\section{Degree of Hydrolytic Capacity}

To reveal which of the isolates produced higher amount of the enzymes, degree of their hydrolytic capacity for degradation of a given substrate were determined and presented as enzyme intensity (EI) in Table 3. On media containing gelatin as the substrate, BDGB11 showed the highest protease production (EI 5.22), followed by BDGB6 (EI 5.08). Lipase production, based on the depolymerization of Tween 80 , was generally found higher; all strains showed an EI of at least 5.0 (Table 3). The maximum lipase production was detected in BDGB17 followed by BDGB4 (EI 8.89 and 7.45, respectively). Three other isolates, BDGB2, BDGB9 and BDGB11, also showed relatively high lipase production (EI 7.3). 
A

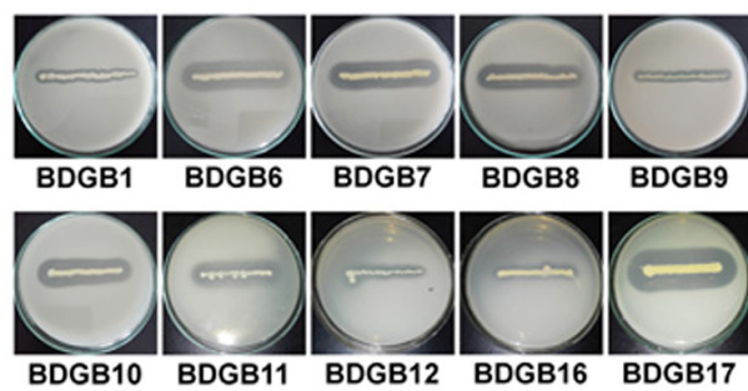

C

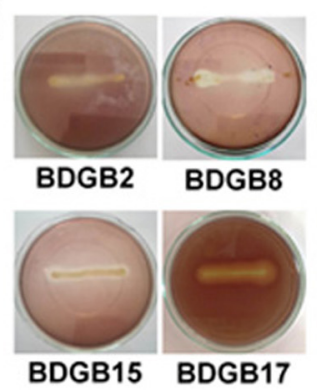

D

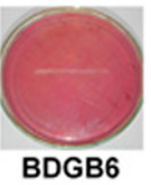

E
B

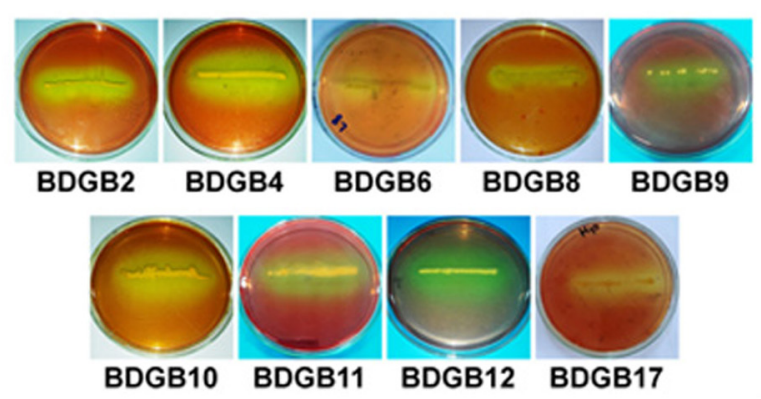

$F_{100}$

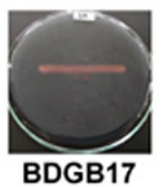

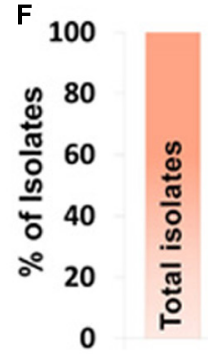

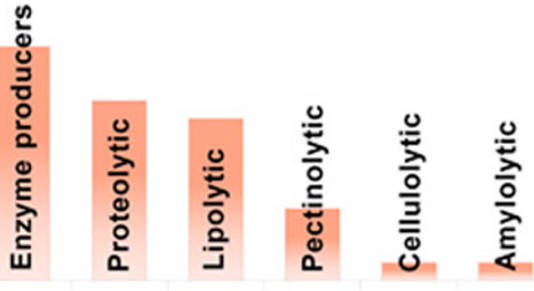

Hydrolytic enzyme activities

FIGURE 1 | Production of extracellular hydrolytic enzymes by the gut-associated bacteria of Bombay duck. Plate assay showing (A) proteolytic, (B) lipolytic, (C) pectinolytic, (D) cellulolytic and (E) amylolytic enzyme activities of the isolated bacteria. The assay was performed by inoculation of the bacterial isolates on agar media containing suitable substrate specific for each enzyme activity. After incubation at $30^{\circ} \mathrm{C}$ for $48 \mathrm{~h}$, media were treated with specific staining solutions to visualize formation of clear halos around bacterial colonies indicating production of the respective enzymes. Isolates that did not produce any halo zone, are not shown. (F) Distribution (\%) of extracellular hydrolytic enzyme activities among the isolates.

TABLE 1 | Hydrolytic enzyme profile of the gut-associated bacteria of Bombay duck.

\begin{tabular}{|c|c|c|c|c|c|}
\hline Isolated strains & \multicolumn{5}{|c|}{ Extracellular hydrolytic enzyme activities } \\
\hline BDGB1 & + & - & - & - & - \\
\hline BDGB2 & - & + & + & - & - \\
\hline BDGB4 & - & + & - & - & - \\
\hline BDGB6 & + & + & - & + & - \\
\hline BDGB9 & + & + & - & - & - \\
\hline BDGB10 & + & + & - & - & - \\
\hline BDGB11 & + & + & - & - & - \\
\hline BDGB12 & + & + & - & - & - \\
\hline BDGB15 & - & - & + & - & - \\
\hline
\end{tabular}

"+" and "-" indicate the presence and absence of the enzyme activities, respectively. BDGB3, BDGB5, BDGB13, and BDGB14 that did not produce any of the five hydrolytic enzymes, are not included.

Similar to the lipase production, BDGB17 showed maximum pectinase production also (EI 6.67). Cellulolytic and amylolytic activities, which were detected in one isolate each viz. BDGB6 and BDGB17, respectively, were, however, produced in very small amounts (EI 1.83 and 2.06, respectively).

Analysis of taxonomic affiliations of the high-produces, e.g., BDGB2, BDGB4, BDGB6, BDGB9, BDGB11, and BDGB17, revealed that they all came from different genera including
Microbacterium, Corynebacterium, Micrococcus, Macrococcus, Staphylococcus and Exiguobacterium, respectively (Table 2). Three of these high-producers (BDGB2, BDGB11, and BDGB17) are particularly worthy of mention because they showed higher expressions of two different enzymes. For example, BDGB2 and BDGB17 both exhibited relatively high expression of lipase and pectinase enzymes, whereas BDGB11 produced higher amounts of protease and lipase enzymes (Table 3). It is also interesting to 


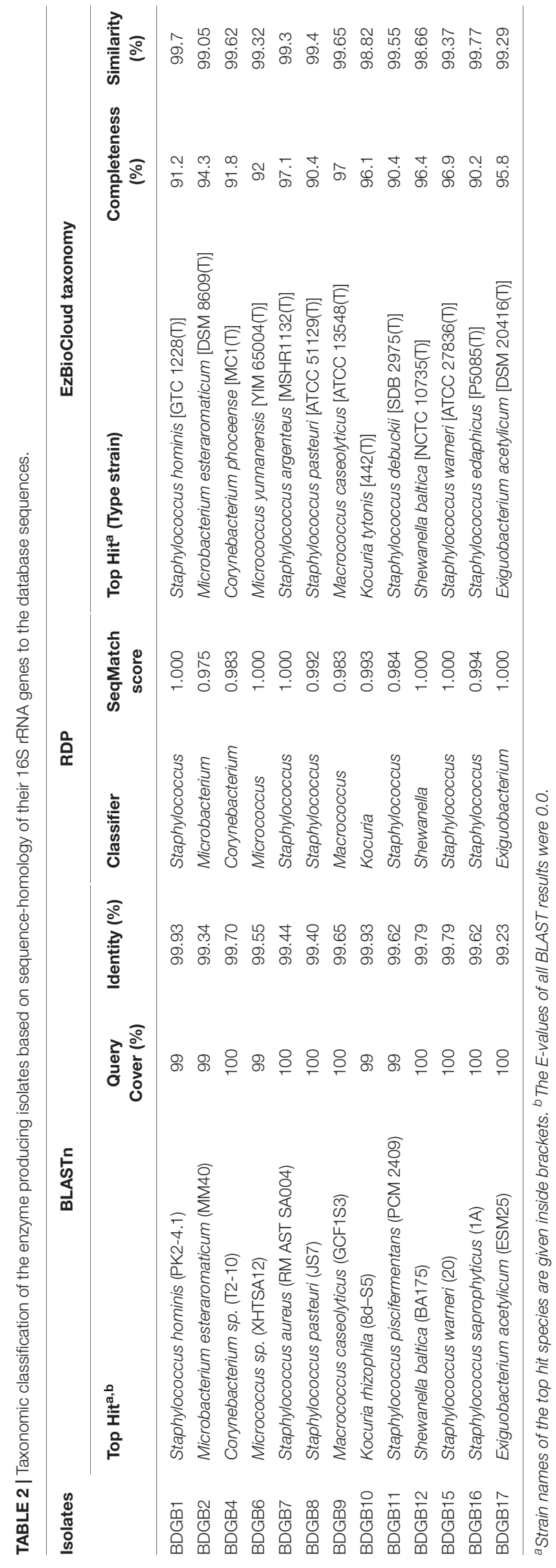

find that the lipolytic activity was expressed not only by a large number of the isolates; it was also produced in amounts higher than all the other hydrolases by most of these isolates (Table 3 ).

\section{DISCUSSION}

Majority (77\%) of the bacteria isolated in this work produced at least one of the five hydrolytic enzymes (Figure 1). The most common of these enzymes were the ones related to the degradation of lipids and proteins. This enzymatic pattern appears to be strongly correlated to the eating behavior of Bombay duck. Being a carnivore, Bombay duck mainly feeds on small animals such as zooplanktons (Zhang and Jin, 2014) suggesting that proteins and lipids comprise major fractions of its diet. With plenty of the dietary substrates available for digestion, predominance of the proteolytic (59\%) and lipolytic (53\%) strains in the GI tract of Bombay duck is normal. This also explains why the cellulolytic and amylolytic activities were found in very small number of the bacteria; lack of the plant-based macromolecules such as cellulose, starch etc. in the diet of Bombay duck implies that the bacteria which rely on their extracellular cellulolytic and/or amylolytic enzymes for nutrition, might not get sufficient nutrients due to the lack of suitable substrates in the host diet. Therefore, the cellulolytic or amylolytic microbes gaining entry into the GI tract, might not want to establish themselves there. Previously, Bairagi et al. (2002) also failed to detect cellulolytic activity in the gut bacteria of two carnivorous fishes, murrel and walking catfish. Moreover, each of the isolates having cellulolytic (BDGB6) or amylolytic (BDGB17) activity in this study, also showed both of the proteolytic and lipolytic activities (Table 1), suggesting that these strains are not exclusively or inevitably dependent on their cellulolytic or amylolytic activity for nutrition. This is also consistent with the finding that the production of the cellulase and amylase enzymes of these isolates was much lower than that of the lipase or protease enzymes (Table 3). Surprisingly, however, pectinolytic activity that degrades pectin, a plant-based biopolymer, was detected in rather higher number $(24 \%)$ of the isolates. While three of these isolates (BDGB2, BDGB8, and BDGB17) also showed proteolytic and/or lipolytic activities, the remaining one (BDGB15) didn't show any additional hydrolytic activity (Table 1). It might be possible that one or more of these pectinolytic strains were transient or occasional visitors (allochthonous) to the GI tract. Reports describing the pectinolytic strains in fish GI tract are, in fact, very scarce. Before the present work, only two groups (Mountfort et al., 1993; Sasmal and Ray, 2015) described the presence of pectinolytic activity in bacteria isolated from the gut of mullet and Tilapia. In general, the percentage of bacteria showing extracellular lipolytic and proteolytic activities in this work is pretty similar to that reported in other studies (Gatesoupe et al., 1997; Sumathi et al., 2011; Ariole et al., 2014; Tiwari et al., 2015). However, findings regarding the percentage of cellulolytic and amylolytic strains are quite different from those in a number of previous reports which described higher proportions of these isolates even in carnivorous fishes (Das and Tripathi, 1991; Sugita et al., 1997; 


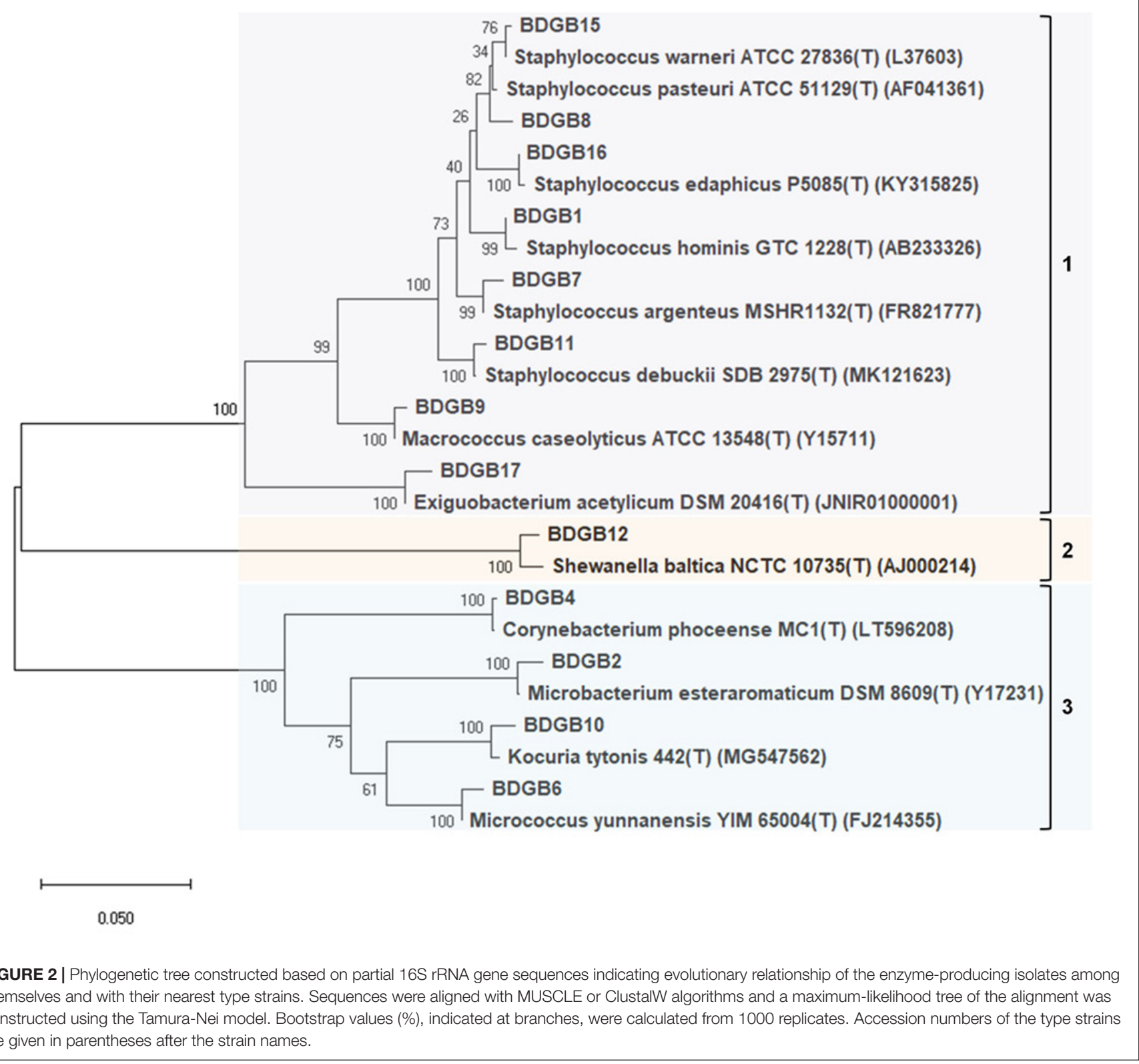

Saha and Ray, 1998; Bairagi et al., 2002; Saha et al., 2006; Mondal et al., 2008, 2010; Ray et al., 2010; Das et al., 2014; Banerjee et al., 2016). In any case, the profile of hydrolytic activities of the isolates revealed in this study, clearly indicates that the gut microbiota of Bombay duck play a very important function in the digestion of the foods it consumes, thus providing essential nutrients to the host. Moreover, the proteolytic populations, in addition to their function in the digestive process, are also known to contribute via their antagonistic and lytic activities against other bacteria and therefore considered very useful as probiotics in aquaculture.

All the isolates identified in this work had 16S rRNA gene sequences highly similar to previously reported GenBank sequences showing over 99\% homology in BLAST's similarity search (Table 2). For each isolate it was found that, one or more of its closest relatives that existed within the topmost bacteria in BLAST's search-result, were also collected from marine environment. For example, S. hominis strain P12B3-1 (ACN: MK318620), M. esteraromaticum strain BA1109 (KC430861), C. phocae strain M408/89/1 (CP009249), M. yunnanensis strain P1-A7 (MK318591), S. aureus strain AM (MG230264), Staphylococcus sp. strain SA02-L01c (MN043814), M. caseolyticus strain GCF1S3 (MG744632), K. rhizophila strain FEB3-08 (MG780345), Staphylococcus sp. strain S8 (MK954148), S. baltica strain BA175 (CP002767), S. saprophyticus strain P0081Karwar, uncultured Exiguobacterium sp. clone CD25 (KF760547) etc. were all obtained from various marine sources such as sea sediment, sea water, intestinal content of marine fish 


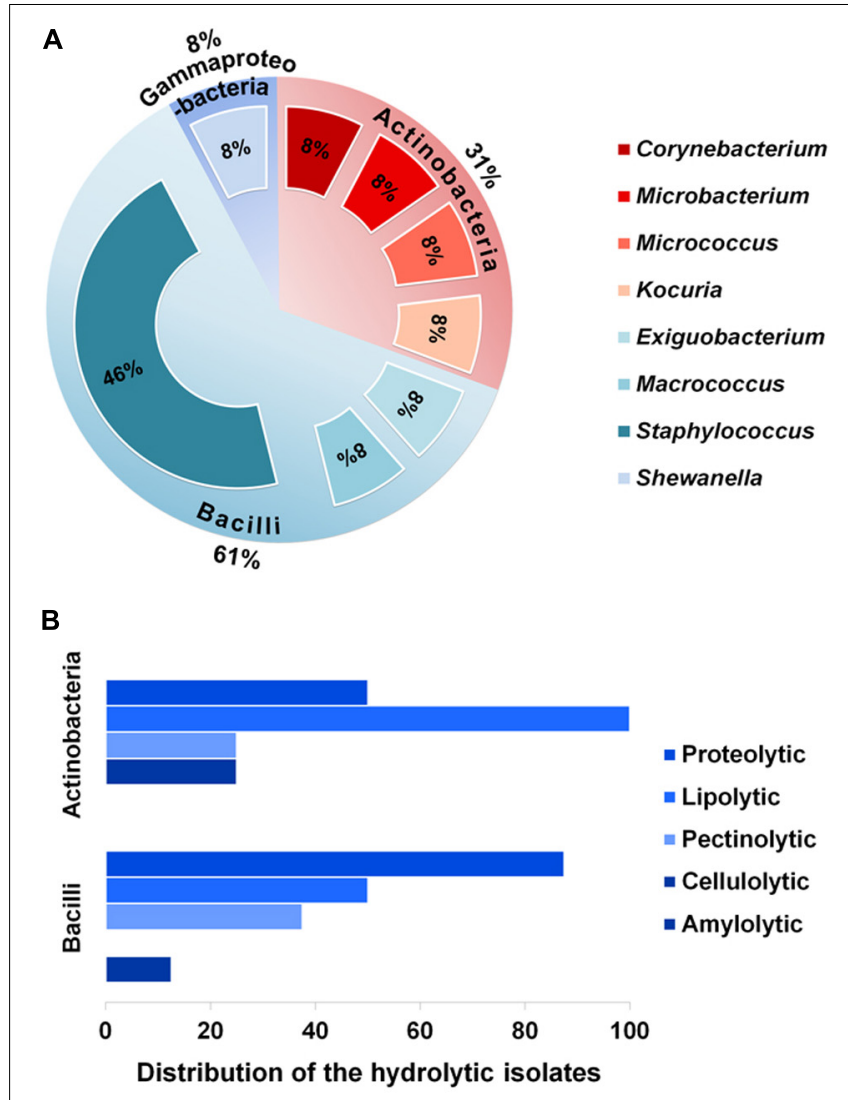

C

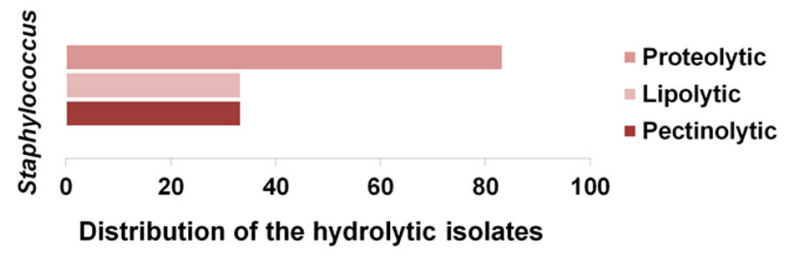

FIGURE 3 | Proportions of the various phylotypes of the enzyme-producing isolates, and distribution of the isolates across these phylotypes.

(A) Proportions (\%) of the taxonomic classes and genera representing the thirteen enzyme-producing isolates. (B) Distribution (\%) of the hydrolytic isolates across the two major classes, i.e., Actinobacteria and Bacilli. (C) Distribution (\%) of proteolytic, lipolytic and pectinolytic isolates across the major genus, Staphylococcus.

etc. This finding is consistent with the origin of the BDGB isolates as marine-derived organisms.

Some of the species identified in the gut of Bombay duck, have been previously shown to exert beneficial effects in other fish. For example, biosurfactant isolated from S. hominis significantly enhanced specific and non-specific immunity and disease resistance in finfish (Rajeswari et al., 2016). In a study on the probiotic characterization of $S$. baltica, a significant increase in the growth of Senegalese sole was found when the fish was fed with a diet supplemented with the bacterial strain (Díaz-Rosales et al., 2009). Besides, an increased immune response as well as resistance against Photobacterium damselae was observed. E. acetylicum, another sp. identified in the present study, exhibited excellent probiotic qualities and is therefore considered as a strong candidate for probiotic applications in aquaculture (Jinendiran et al., 2019a,b). Jinendiran et al. demonstrated that dietary supplementation of E. acetylicum resulted in a significant enhancement of the growth, hematological profile and cellular immune responses including respiratory burst, phagocytic activities, total immunoglobulin levels and antimicrobial enzymes in goldfish (Jinendiran et al., 2019b). Moreover, both goldfish and brine shrimp when fed with $E$. acetylicum showed a significantly higher survival rate against Aeromonas hydrophila (Jinendiran et al., 2019a,b). The E. acetylicum sp. has also been shown to be involved in the innate immune response in Zebrafish (Murdoch and Rawls, 2019).

Considering hydrolytic capacity, the Exiguobacterium sp. (BDGB17) appeared to be the most promising strain of all the bacteria isolated in the present study. It expressed maximum number of the hydrolytic enzymes and also showed highest production of two of those hydrolases. Exiguobacterium is comparatively a newly-described genus; yet several of its species have already gained much attention for their unique properties that are useful in the biotechnology, bioremediation, agriculture and industrial processes (Kasana and Pandey, 2018). In accordance with the results found in this study, other reports also described production of hydrolytic enzymes by Exiguobacterium sp. such as protease, lipase, pectinase and amylase, in addition to other hydrolases (Kasana and Pandey, 2018) not investigated in this research. The strain described by Vijayalaxmi et al. was able to produce cellulase (Vijayalaxmi et al., 2013), though BDGB17 of the present study showed negative results in the cellulase plate assay under the culture condition used. Spp. of Exiguobacterium were isolated from a wide range of environments including few marine sources (Kasana and Pandey, 2018) but before this work, only one study documented the presence of this sp. in the gastrointestinal tract of vertebrates (Jammal et al., 2017). Its identification in the gut of Liza aurata in that study was, however, not conclusive at the species level showing $97 \%$ similarity of the 16 S rRNA gene sequence with the closest match. Two other isolates of the present work, BDGB6 and BDGB8 which produced the second-highest number of the hydrolases, belonged to Micrococcus and Staphylococcus groups, respectively. Strains belonging to these two groups were, however, reported to be isolated from fish digestive tract and are also known to produce a number of different extracellular hydrolytic enzymes (Ray et al., 2012).

The bacteria of this work were found moderately diverse in their taxonomic groups. In fact, bacterial diversity in the fish gut is generally lower in carnivores, and progressively increases in omnivores and herbivores (Liu et al., 2016; Butt and Volkoff, 2019). Moreover, bacteria identified in the present work were obtained from two fish; inclusion of more fish might help in a better rationalization of the microbial diversity in fish gut. The identified species represent three different bacterial phyla: Firmicutes, Actinobacbacteria and Gammaproteobacteria. These three phyla have been reported to predominate in the gut microbiota of many other fishes such as sea bream, grass carp, 
TABLE 3 | Amount of extracellular hydrolytic enzymes produced by the bacterial isolates expressed as enzyme intensity (El).

\begin{tabular}{|c|c|c|c|c|c|}
\hline \multirow[t]{2}{*}{ Isolates } & \multicolumn{5}{|c|}{ Enzyme Intensity (EI) } \\
\hline & Protease & Lipase & Pectinase & Cellulase & Amylase \\
\hline BDGB1 & $2.67 \pm 0.38$ & & & & \\
\hline BDGB2 & & $7.22 \pm 2.54$ & $5.31 \pm 0.93$ & & \\
\hline BDGB4 & & $7.45 \pm 1.26$ & & & \\
\hline BDGB6 & $5.08 \pm 0.14$ & $5.42 \pm 0.72$ & & $1.83 \pm 0.29$ & \\
\hline BDGB7 & $5.00 \pm 0.25$ & & & & \\
\hline BDGB8 & $3.87 \pm 0.11$ & $6.70 \pm 0.75$ & $4.17 \pm 0.14$ & & \\
\hline BDGB9 & $1.97 \pm 0.05$ & $7.30 \pm 0.82$ & & & \\
\hline BDGB10 & $4.89 \pm 0.19$ & $5.08 \pm 0.14$ & & & \\
\hline BDGB11 & $5.22 \pm 0.19$ & $7.22 \pm 2.41$ & & & \\
\hline BDGB12 & $4.83 \pm 0.29$ & $5.33 \pm 0.58$ & & & \\
\hline BDGB15 & & & $2.00 \pm 0.43$ & & \\
\hline BDGB16 & $1.92 \pm 0.14$ & & & & \\
\hline BDGB17 & $4.33 \pm 0.08$ & $8.89 \pm 0.96$ & $6.67 \pm 0.33$ & & $2.06 \pm 0.42$ \\
\hline
\end{tabular}

Data represent the mean \pm standard deviation of three independent experiments.

rainbow trout, coho salmon, zebrafish etc. (Rawls et al., 2004; Romero and Navarrete, 2006; Navarrete et al., 2009, 2012; Wu et al., 2012; Estruch et al., 2015). Moreover, similar to the findings of the present study, members of the three phyla were also found to make an important contribution to the digestive process of the host by providing a variety of hydrolytic enzymes (Hamid et al., 1979; Gatesoupe et al., 1997; Bairagi et al., 2002; Navarrete et al., 2012; Ray et al., 2012; Egerton et al., 2018; Butt and Volkoff, 2019). No sp. from Bacteroidetes was, however, identified in the present work though members from this phylum are usually common being reported previously in seabass, Kyphosus cinerascens etc. (Carda-Diéguez et al., 2014). Spp. of the less common phyla such as Fusobacteria, Flavobacteria etc. (Llewellyn et al., 2014; Wang et al., 2018) were also absent among the hydrolytic bacteria isolated in the present study. In fact, the bacterial diversity in fish gut depends on a variety of factors (Egerton et al., 2018; Talwar et al., 2018). One of the most important of these factors is the type of the host diet which in turn depends on the feeding behavior of the fish and both have been found to directly influence the microbiota structure of GI tract (Ray et al., 2012; Egerton et al., 2018; Butt and Volkoff, 2019). Connection between the host diet and gut microbial composition is clearly evident from the findings of the present study also, as already discussed. Another important factor, in addition to the host diet and trophic level, is the environmental condition of the habitat such as the water temperature (Egerton et al., 2018). Previously Huyben et al. showed that raising water temperature from 11 to $18^{\circ} \mathrm{C}$ resulted in an increase of both bacterial abundance and diversity in the gut microbiota of rainbow trout, while the optimal growth temperature of the fish is as high as $17^{\circ} \mathrm{C}$ (Huyben et al., 2018). Waché et al. (2006) also reported a change in the gut bacterial load in rainbow trout resulting from changes in water temperatures. Other reports suggested, however, that increase of water temperature above $17^{\circ} \mathrm{C}$ can induce stress, reduce growth and may disrupt microbial communities in the gut of this fish (Huyben et al., 2018). The habitat of Bombay duck includes the tropical waters of Indo-Pacific including Indian
Ocean and the Bay of Bengal (Zhang et al., 2017). Waters in this region maintain temperatures of $>28^{\circ} \mathrm{C}$ at the sea-surface the whole year round (De Deckker, 2016). Besides, those waters maintain such temperatures down to approximately $200 \mathrm{~m}$ in most regions, an environment that appears to be preferred by Bombay duck (Sundara Raj, 1954; Bapat, 1970; De Deckker, 2016). Hence, bacteria in the present study were isolated and grown at $30^{\circ} \mathrm{C}$ to match the temperature of their natural environment. Some of these bacteria were also isolated from the gut of other marine and fresh water fishes. For example, in an analysis of the GI microbiota of Mediterranean fish, Jammal et al. (2017) reported identification of S. baltica in seven out of the fifteen fish species they've examined including Sargocentron rubrum, Dentex macrophthalmus, Dicologlossa cuneata, Oblada melanura, Pempheris rhomboidea, Sardinella maderensis, and Lithognathus mormyrus. In fact, the Shewanella sp. appears to be a bacterium frequently found in the GI microbial community of fishes. In addition to the above seven fish species, this bacterium was also identified in the intestine of lean lake trout, pufferfish and whitefish (Coregonus clupeaformis) (Dailey et al., 2016; Castillo et al., 2018; Li et al., 2020). Alongside S. baltica, Jammal et al. identified two other spp. of the present work: S. hominis and K. rhizophila that were isolated from S. rubrum and $S$. rivulatus, respectively. In fact, the Staphylococcus spp. seem pretty common in the fish intestine. In addition to the S. hominis sp. described above, three more Staphylococcus spp. of the present investigation were identified in the gut of other fish species. S. warneri and S. pasteuri, for example, were reported in the intestine of Atlantic salmon in several individual research (Bakke-McKellep et al., 2007; Askarian et al., 2011; Abid et al., 2013); the latter sp. was also identified in the intestine of gibel carp (Carassius auratus) as well as in the fresh water fish Nile tilapia (He et al., 2011; Wu et al., 2020). Fish in those studies were, however, fed with specific diets. Another Staphylococcus species of this study, S. saprophyticus, was reported in the intestine of a variety of fish species including flatfish, butterfly peacock bass, Malaysian mahseer, orange-spotted grouper, Mozambique 
tilapia and Nile tilapia (Silva and Widanapathirana, 1984; Sun et al., 2011; Sivakumar et al., 2015; Nosi et al., 2018; Wanka et al., 2018). Therefore, the S. saprophyticus isolate together with $S$. baltica appear to be very common members of fish GI microbiota, suggesting that they both are autochthonous species.

In summary, this study showed that the GI tract of Bombay duck harbors diverse bacterial populations producing various extracellular hydrolytic enzymes including proteases, lipases and pectinases in particular. The enzyme producing capacity of the isolates suggests that the gut bacterial flora serves as an important source of digestive enzymes for the host and plays important roles in the host's digestive metabolism and nutrition. The results also highlight the importance of fish GI microbiota for bioprospection of industrially useful enzymes. The isolates that showed high activities in this study merit further investigations to understand their actual capacity to produce the hydrolytic enzymes which could lead to their important industrial applications.

\section{DATA AVAILABILITY STATEMENT}

The datasets presented in this study can be found in NCBI Data Bank. The accession number(s) can be found in the article/Material and Methods.

\section{AUTHOR CONTRIBUTIONS}

TH conceived and supervised the project. TH and SC designed the experiments. SC, TH, HM, MC, FA, NR, and SD conducted the experiments. $\mathrm{TH}$ analyzed the results and prepared and

\section{REFERENCES}

Abid, A., Davies, S. J., Waines, P., Emery, M., Castex, M., Gioacchini, G., et al. (2013). Dietary synbiotic application modulates Atlantic salmon (Salmo salar) intestinal microbial communities and intestinal immunity. Fish Shellfish Immunol. 35, 1948-1956. doi: 10.1016/j.fsi.2013. 09.039

Aldrich, J. (1997). R.A. Fisher and the making of maximum likelihood 1912-1922. Statist. Sci. 12, 162-176. doi: 10.1214/ss/1030037906

Aleem, B., Rashid, M. H., Zeb, N., Saqib, A., Ihsan, A., Iqbal, M., et al. (2018). Random mutagenesis of super Koji (Aspergillus oryzae): improvement in production and thermal stability of $\alpha$-amylases for maltose syrup production. BMC Microbiol. 18:200. doi: 10.1186/s12866-018-1345-y

Amoozegar, M. A., Malekzadeh, F., and Malik, K. A. (2003). Production of amylase by newly isolated moderate halophile, Halobacillus sp. strain MA-2. J. Microbiol. Methods 52, 353-359. doi: 10.1016/S0167-7012(02)00191-4

Ananthi, S., Ramasubburayan, R., Palavesam, A., and Immanuel, G. (2014). Optimization and purification of lipase through solid state fermentation by bacillus cereus MSU as isolated from the gut of a marine fish Sardinella longiceps. Int. J. Pharm. Pharm. Sci. 6, 291-298.

Ariole, C. N., Nwogu, H. A., and Chuku, P. W. (2014). Enzymatic activities of intestinal bacteria isolated from farmed Clarias gariepinus. Int. J. Aquac. 4, 108-112. doi: 10.5376/ija.2014.04.0018

Ashok, A., Doriya, K., Rao, J. V., Qureshi, A., Tiwari, A. K., and Kumar, D. S. (2019). Microbes producing L-Asparaginase free of glutaminase and urease isolated from extreme locations of antarctic soil and moss. Sci. Rep. 9:1423. doi: 10.1038/s41598-018-38094-1

Askarian, F., Zhou, Z., Olsen, R. E., Sperstad, S., and Ringø, E. (2011). Culturable autochthonous gut bacteria in Atlantic salmon (Salmo salar L.) fed diets with wrote the manuscript. All authors reviewed and approved the manuscript.

\section{FUNDING}

This work was partially funded by University of Chittagong via its Research and Publication Cell to TH.

\section{ACKNOWLEDGMENTS}

The authors gratefully acknowledge the generous help from Dr. Mohammad M. Islam, Department of Biochemistry and Molecular Biology, University of Chittagong (BMB, CU) allowing access to his laboratory facilities and also thank him for his suggestions and encouragement. The authors thank Dr. Chowdhury M. M. Hasan, BMB, CU for kindly providing a few chemicals. Special thanks to Ms. Mukta Das, Ms. Khadiza Akhter, and Ms. Asma Akter of the Laboratory of Applied Microbiology and Pathogenesis, BMB, CU for their help. The authors are grateful to Professor Ahmad Hossain, Southern University Bangladesh for his advice.

\section{SUPPLEMENTARY MATERIAL}

The Supplementary Material for this article can be found online at: https://www.frontiersin.org/articles/10.3389/fmicb. 2020.02097/full\#supplementary-material

or without chitin. Characterization by $16 \mathrm{~S}$ rRNA gene sequencing, ability to produce enzymes and in vitro growth inhibition of four fish pathogens. Aquaculture 326-329, 1-8. doi: 10.1016/j.aquaculture.2011.10.016

Bairagi, A., Ghosh, K. S., Sen, S. K., and Ray, A. K. (2002). Enzyme producing bacterial flora isolated from fish digestive tracts. Aquac. Int. 10, 109-121. doi: 10.1023/A:1021355406412

Bakke-McKellep, A. M., Penn, M. H., Salas, P. M., Refstie, S., Sperstad, S., Landsverk, T., et al. (2007). Effects of dietary soyabean meal, inulin and oxytetracycline on intestinal microbiota and epithelial cell stress, apoptosis and proliferation in the teleost Atlantic salmon (Salmo salar L.). Br. J. Nutr. 97, 699-713. doi: 10.1017/S0007114507381397

Balli, J. J., Chakraborty, S. K., and Jaiswar, A. K. (2006). Biology of Bombay duck, Harpodon nehereus (Ham., 1822), from Mumbai waters, India. J. Indian Fish. Assoc. 33, 1-10.

Banerjee, G., Mukherjee, S., Bhattacharya, S., and Ray, A. K. (2016). Purification and characterization of extracellular protease and amylase produced by the bacterial strain, Corynebacterium alkanolyticum ATH3 isolated from fish gut. Arab. J. Sci. Eng. 41, 9-16. doi: 10.1007/s13369-015-1809-4

Banerjee, G., and Ray, A. K. (2017). Bacterial symbiosis in the fish gut and its role in health and metabolism. Symbiosis 72, 1-11. doi: 10.1007/s13199-016-0441-8

Bapat, S. V. (1967). The Bombay-Duck. Available online at: http://eprints.cmfri.org. in/5555/ (accessed March 9, 2019).

Bapat, S. V. (1970). Bombay duck, Harpodon nehereus (Ham.). CMFRI Bull. 21, $1-75$.

Behera, S., Biswas, B. K., Kumar, S., and Gogoi, R. (2015). Length-weight relationship and condition factors of Bombay duck, Harpodon nehereus from estuarine region of Kakdwip West Bengal. J. Bio Innov. 4, 59-66.

Butt, R. L., and Volkoff, H. (2019). Gut microbiota and energy homeostasis in fish. Front. Endocrinol. 10:9. doi: 10.3389/fendo.2019.00009 
Carda-Diéguez, M., Mira, A., and Fouz, B. (2014). Pyrosequencing survey of intestinal microbiota diversity in cultured sea bass (Dicentrarchus labrax) fed functional diets. FEMS Microbiol. Ecol. 87, 451-459. doi: 10.1111/1574-6941. 12236

Castillo, D., Gram, L., and Dailey, F. E. (2018). Genome sequences of Shewanella baltica and Shewanella morhuae strains isolated from the gastrointestinal tract of freshwater fish. Genome Announc. 6:e00541-18. doi: 10.1128/genomeA. 00541- 18

Cole, J. R., Wang, Q., Fish, J. A., Chai, B., McGarrell, D. M., Sun, Y., et al. (2014). Ribosomal Database Project: data and tools for high throughput rRNA analysis. Nucleic Acids Res. 42, D633-D642. doi: 10.1093/nar/gkt1244

Dailey, F. E., McGraw, J. E., Jensen, B. J., Bishop, S. S., Lokken, J. P., Dorff, K. J., et al. (2016). The microbiota of freshwater fish and freshwater niches contain omega-3 fatty acid-producing shewanella species. Appl. Environ. Microbiol. 82, 218-231. doi: 10.1128/AEM.02266-15

Das, K. M., and Tripathi, S. D. (1991). Studies on the digestive enzymes of grass carp, Ctenopharyngodon idella (Val.). Aquaculture 92, 21-32. doi: 10.1016/ 0044-8486(91)90005-R

Das, P., Mandal, S., Khan, A., Manna, S. K., and Ghosh, K. (2014). Distribution of extracellular enzyme-producing bacteria in the digestive tracts of 4 brackish water fish species. Turk. J. Zool. 38, 79-88. doi: 10.3906/zoo-1205-3

Das, S., Lyla, P. S., and Khan, S. A. (2006). Marine microbial diversity and ecology: importance and future perspectives. Curr. Sci. 90, 1325-1335.

Dash, H. R., Mangwani, N., Chakraborty, J., Kumari, S., and Das, S. (2013). Marine bacteria: potential candidates for enhanced bioremediation. Appl. Microbiol. Biotechnol. 97, 561-571. doi: 10.1007/s00253-012-4584-4580

de Carvalho, C. C. C. R., and Fernandes, P. (2010). Production of metabolites as bacterial responses to the marine environment. Mar. Drugs 8, 705-727. doi: $10.3390 / \mathrm{md} 8030705$

Debashish, G., Malay, S., Barindra, S., and Joydeep, M. (2005). "Marine enzymes," in Marine Biotechnology I Advances in Biochemical Engineering/Biotechnology, eds R. Ulber and Y. Le Gal (Berlin: Springer), 189-218.

De Deckker, P. (2016). The indo-pacific warm pool: critical to world oceanography and world climate. Geosci. Lett. 3:20. doi: 10.1186/s40562-016-0054-3

Díaz-Rosales, P., Arijo, S., Chabrilloìn, M., Alarcoìn, F. J., Tapia-Paniagua, S. T., Martiìnez-Manzanares, E., et al. (2009). Effects of two closely related probiotics on respiratory burst activity of Senegalese sole (Solea senegalensis, Kaup) phagocytes, and protection against Photobacterium damselae subsp. piscicida. Aquaculture 293, 16-21. doi: 10.1016/j.aquaculture.2009.03.050

Egerton, S., Culloty, S., Whooley, J., Stanton, C., and Ross, R. P. (2018). The gut microbiota of marine fish. Front. Microbiol. 9:873. doi: 10.3389/fmicb.2018 00873

Esakkiraj, P., Immanuel, G., Sowmya, S. M., Iyapparaj, P., and Palavesam, A. (2008). Evaluation of protease-producing ability of fish gut isolate Bacillus cereus for aqua feed. Food Bioprocess Technol. 2, 383. doi: 10.1007/s11947-0070046-6

Estruch, G., Collado, M. C., Peñaranda, D. S., Vidal, A. T., Cerdá, M. J., Martínez G. P., et al. (2015). Impact of fishmeal replacement in diets for gilthead sea bream (Sparus aurata) on the gastrointestinal microbiota determined by pyrosequencing the 16S rRNA gene. PLoS One 10:e0136389. doi: 10.1371/ journal.pone.0136389

Finore, I., Di Donato, P., Mastascusa, V., Nicolaus, B., and Poli, A. (2014). Fermentation technologies for the optimization of marine microbial exopolysaccharide production. Mar. Drugs 12, 3005-3024. doi: 10.3390/ md12053005

Fry, S. M., Huang, J. S., and Milholland, R. D. (1994). Isolation and preliminary characterization of extracellular proteases produced by stains of Xylella fastidiosa from grapevines. Phytopathology 84, 357-363.

Gatesoupe, F.-J., Infante, J.-L. Z., Cahu, C., and Quazuguel, P. (1997). Early weaning of seabass larvae, Dicentrarchus labrax: the effect on microbiota, with particular attention to iron supply and exoenzymes. Aquaculture 158, 117-127. doi: 10.1016/S0044-8486(97)00179-8

Ghosh, S. (2014). Fishery, reproductive biology and diet characteristics of Bombay duck Harpadon nehereus from the Saurashtra coast. Indian J. Geo Mar. Sci. 43, $418-426$.

Gurung, N., Ray, S., Bose, S., and Rai, V. (2013). A broader view: microbial enzymes and their relevance in industries, medicine, and beyond. BioMed Res. Int. 2013:329121. doi: 10.1155/2013/329121
Hamid, A., Sakata, T., and Sakimoto, D. (1979). Microflora in the Alimentary Tract of Gray Mullet-IV. 45, 99-106. doi: 10.2331/suisan.45.99

He, S., Wan, Q., Ren, P., Yang, Y., Yao, F., and Zhou, Z. (2011). The effect of dietary saccharoculture on growth performance, non-specific immunity and autochthonous gut microbiota of gibel Carp Carassius auratus. J. Aquac. Res. Dev. 1, 1-6. doi: 10.4172/2155-9546.S1-010

He, X., Li, J., Shen, C., Shi, Y., Feng, C., Guo, J., et al. (2018). Length-weight relationship and population dynamics of bombay duck (Harpadon nehereus) in the Min River Estuary, East China Sea. Thalassas 35, 253-261. doi: 10.1007/ s41208-018-0117-7

Hossain, T. J., Alam, M. K., and Sikdar, D. (2011). Chemical and microbiological quality assessment of raw and processed liquid market milks of Bangladesh. Continent. J. Food Sci. Technol. 5, 6-17.

Hossain, T. J., Manabe, S., Ito, Y., Iida, T., Kosono, S., Ueda, K., et al. (2018) Enrichment and characterization of a bacterial mixture capable of utilizing C-mannosyl tryptophan as a carbon source. Glycoconjugate J. 35, 165-176. doi: 10.1007/s10719-017-9807-2

Huyben, D., Sun, L., Moccia, R., Kiessling, A., Dicksved, J., and Lundh, T. (2018). Dietary live yeast and increased water temperature influence the gut microbiota of rainbow trout. J. Appl. Microbiol. 124, 1377-1392. doi: 10.1111/jam.13738

Jammal, A., Bariche, M., zu Dohna, H., and Kambris, Z. (2017). Characterization of the cultivable gut microflora in wild-caught mediterranean fish species. Curr. Nutr. Food Sci. 13, 147-154. doi: 10.2174/1573401313666170216165332

Jinendiran, S., Boopathi, S., Sivakumar, N., and Selvakumar, G. (2019a). Functional characterization of probiotic potential of novel pigmented bacterial strains for aquaculture applications. Probiotics Antimicrob. Proteins 11, 186-197. doi: 10. 1007/s12602-017-9353-Z

Jinendiran, S., Nathan, A. A., Ramesh, D., Vaseeharan, B., and Sivakumar, N. (2019b). Modulation of innate immunity, expression of cytokine genes and disease resistance against Aeromonas hydrophila infection in goldfish (Carassius auratus) by dietary supplementation with Exiguobacterium acetylicum S01. Fish Shellfish Immunol. 84, 458-469. doi: 10.1016/j.fsi.2018.10. 026

Johnson, M., Zaretskaya, I., Raytselis, Y., Merezhuk, Y., McGinnis, S., and Madden, T. L. (2008). NCBI BLAST: a better web interface. Nucleic Acids Res. 36, W5-W9. doi: 10.1093/nar/gkn201

Kasana, R. C., and Pandey, C. B. (2018). Exiguobacterium: an overview of a versatile genus with potential in industry and agriculture. Crit. Rev. Biotechnol. 38, 141-156. doi: 10.1080/07388551.2017.1312273

Kawashima, S., Ikehata, H., Tada, C., Ogino, T., Kakizaki, H., Ikeda, M., et al. (2016). Stomach chitinase from Japanese sardine Sardinops melanostictus: purification, characterization, and molecular cloning of chitinase isozymes with a long linker. Mar. Drugs 14:22. doi: 10.3390/md14010022

Khan, M. Z., Kurup, K. N., and Lipton, A. P. (1992). Status of Bombay duck Harpodon nehereus (Ham.) resource off Saurashtra coast. Indian J. Fish. 39, 235-242.

Kirk, O., Borchert, T. V., and Fuglsang, C. C. (2002). Industrial enzyme applications. Curr. Opin. Biotechnol. 13, 345-351. doi: 10.1016/S0958-1669(02) 00328-2

Krishnan, S., Alden, N., and Lee, K. (2015). Pathways and functions of gut microbiota metabolism impacting host physiology. Curr. Opin. Biotechnol. 36, 137-145. doi: 10.1016/j.copbio.2015.08.015

Kumar, S., Stecher, G., Li, M., Knyaz, C., and Tamura, K. (2018). MEGA X: molecular evolutionary genetics analysis across computing platforms. Mol. Biol. Evol. 35, 1547-1549. doi: 10.1093/molbev/msy096

Kurian, A. (2000). “The Bombay duck: stock status and response to exploitation," in Marine Fisheries Research and Management, eds V. N. Pillai and N. G. Menon (Kochi: CMFRI Kochi), 349-363.

Lazado, C. C., Caipang, C. M. A., and Kiron, V. (2012). Enzymes from the gut bacteria of Atlantic cod, Gadus morhua and their influence on intestinal enzyme activity. Aquac. Nutr. 18, 423-431. doi: 10.1111/j.1365-2095.2011.00928.x

Lee, H. S., Kwon, K. K., Kang, S. G., Cha, S.-S., Kim, S.-J., and Lee, J.-H. (2010). Approaches for novel enzyme discovery from marine environments. Curr. Opin. Biotechnol. 21, 353-357. doi: 10.1016/j.copbio.2010.01.015

Li, Z., Tian, J., Lai, Y., Lee, C.-H., Cai, Z., and Yu, C.-F. (2020). Puffer fish gut microbiota studies revealed unique bacterial co-occurrence patterns and new insights on tetrodotoxin producers. Mar. Drugs 18:278. doi: 10.3390/ md18050278 
Liu, H., Guo, X., Gooneratne, R., Lai, R., Zeng, C., Zhan, F., et al. (2016). The gut microbiome and degradation enzyme activity of wild freshwater fishes influenced by their trophic levels. Sci. Rep. 6:24340. doi: 10.1038/srep24340

Liu, X., and Kokare, C. (2017). "Chapter 11 - microbial enzymes of use in industry," in Biotechnology of Microbial Enzymes, ed. G. Brahmachari (Cambridge, MA: Academic Press), 267-298. doi: 10.1016/b978-0-12-803725-6.00011-x

Llewellyn, M. S., Boutin, S., Hoseinifar, S. H., and Derome, N. (2014). Teleost microbiomes: the state of the art in their characterization, manipulation and importance in aquaculture and fisheries. Front. Microbiol. 5:207. doi: 10.3389/ fmicb.2014.00207

Meddeb-Mouelhi, F., Moisan, J. K., and Beauregard, M. (2014). A comparison of plate assay methods for detecting extracellular cellulase and xylanase activity. Enzyme Microb. Technol. 66, 16-19. doi: 10.1016/j.enzmictec.2014. 07.004

Miyoshi, T., Iwatsuki, T., and Naganuma, T. (2005). Phylogenetic characterization of 16S rRNA gene clones from deep-groundwater microorganisms that pass through 0.2-micrometer-pore-size filters. Appl. Environ. Microbiol. 71, 10841088. doi: 10.1128/AEM.71.2.1084-1088.2005

Mondal, S., Roy, T., and Ray, A. K. (2010). Characterization and identification of enzyme-producing bacteria isolated from the digestive tract of bata, labeo bata. J. World Aquac. Soc. 41, 369-377. doi: 10.1111/j.1749-7345.2010.00378.x

Mondal, S., Roy, T., Sen, S. K., and Ray, A. K. (2008). Distribution of enzymeproducing bacteria in the digestive tracts of some freshwater fish. Acta Ichthyol. Piscatoria 38, 1-8. doi: 10.3750/aip2008.38.1.01

Mookerjee, H. K., Ganguly, D. N., and Mazumdar, T. C. (1946). On the food of estuarine fish of Bengal. Sci. Cult. 10, 564-565.

Mountfort, D. O., Grant, W. D., Morgan, H., Rainey, F. A., and Stackebrandt, E. (1993). Isolation and characterization of an obligately anaerobic, pectinolytic, member of the genus Eubacterium from mullet gut. Arch. Microbiol. 159, 289-295. doi: 10.1007/BF00248486

Murdoch, C. C., and Rawls, J. F. (2019). Commensal microbiota regulate vertebrate innate immunity-insights from the zebrafish. Front. Immunol. 10:2100. doi: 10.3389/fimmu.2019.02100

Navarrete, P., Magne, F., Araneda, C., Fuentes, P., Barros, L., Opazo, R., et al. (2012). PCR-TTGE analysis of 16S rRNA from rainbow trout (Oncorhynchus mykiss) gut microbiota reveals host-specific communities of active bacteria. PLoS One 7:e31335. doi: 10.1371/journal.pone.0031335

Navarrete, P., Magne, F., Mardones, P., Riveros, M., Opazo, R., Suau, A., et al. (2009). Molecular analysis of intestinal microbiota of rainbow trout (Oncorhynchus mykiss). FEMS Microbiol. Ecol. 71, 148-156. doi: 10.1111/j.15746941.2009.00769.x

Newman, D. J., and Hill, R. T. (2006). New drugs from marine microbes: the tide is turning. J. Ind. Microbiol. Biotechnol. 33, 539-544. doi: 10.1007/s10295-0060115-2

Nikolaivits, E., Dimarogona, M., Fokialakis, N., and Topakas, E. (2017). Marinederived biocatalysts: importance, accessing, and application in aromatic pollutant bioremediation. Front. Microbiol. 8:265. doi: 10.3389/fmicb.2017. 00265

Nosi, M. Z. M., Fadaak, S. N. E. S. J., Muhammad, M. D. D., and Iehata, S. (2018). Assessment of gut microbiota in different developmental stages of Malaysian Mahseer (Tor tambroides). Aquac. Res. 49, 2977-2987. doi: 10.1111/are. 13757

Parte, S., Sirisha, V. L., and D’Souza, J. S. (2017). “Chapter four - biotechnological applications of marine enzymes from algae, bacteria, fungi, and sponges," in Advances in Food and Nutrition Research Marine Enzymes Biotechnology: Production and Industrial Applications, Part III - Application of Marine Enzymes, eds S.-K. Kim and F. Toldrá (Cambridge, MA: Academic Press), 75-106. doi: 10.1016/bs.afnr.2016.10.005

Penesyan, A., Kjelleberg, S., and Egan, S. (2010). Development of novel drugs from marine surface associated microorganisms. Mar. Drugs 8, 438-459. doi: $10.3390 / \mathrm{md} 8030438$

Pillay, T. V. R. (1953). The food and feeding habits of the Bombay duck, Harpodon nehereus (Ham.), in the River Matlah (Bengal). Proc. Natl. Inst. Sci. India 19, 427-435.

Rajeswari, V., Kalaivani Priyadarshini, S., Saranya, V., Suguna, P., and Shenbagarathai, R. (2016). Immunostimulation by phospholipopeptide biosurfactant from Staphylococcus hominis in Oreochromis mossambicus. Fish Shellfish Immunol. 48, 244-253. doi: 10.1016/j.fsi.2015.11.006
Rao, T. E., Imchen, M., and Kumavath, R. (2017). "Chapter Seven Marine enzymes: production and applications for human health," in Advances in Food and Nutrition Research Marine Enzymes Biotechnology: Production and Industrial Applications, Part III - Application of Marine Enzymes, eds S.-K. Kim and F. Toldrá (Cambridge, MA: Academic Press), $149-163$.

Rawls, J. F., Samuel, B. S., and Gordon, J. I. (2004). Gnotobiotic zebrafish reveal evolutionarily conserved responses to the gut microbiota. PNAS 101, 45964601. doi: 10.1073/pnas.0400706101

Ray, A. K., Bairagi, A., Ghosh, K. S., and Sen, S. K. (2007). Optimization of fermentation conditions for cellulase production by Bacillus subtilis CY5 and Bacillus circulans TP3 isolated from fish gut. Acta Ichthyol. Piscatoria 1, 47-53. doi: 10.3750/aip2007.37.1.07

Ray, A. K., Ghosh, K., and Ringø, E. (2012). Enzyme-producing bacteria isolated from fish gut: a review. Aquac. Nutr. 18, 465-492. doi: 10.1111/j.1365-2095. 2012.00943.x

Ray, A. K., Roy, T., Mondal, S., and Ringø, E. (2010). Identification of gutassociated amylase, cellulase and protease-producing bacteria in three species of Indian major carps. Aquac. Res. 41, 1462-1469. doi: 10.1111/j.1365-2109.2009. 02437.x

Romano, G., Costantini, M., Sansone, C., Lauritano, C., Ruocco, N., and Ianora, A. (2017). Marine microorganisms as a promising and sustainable source of bioactive molecules. Mar. Environ. Res. 128, 58-69. doi: 10.1016/j.marenvres. 2016.05.002

Romero, J., and Navarrete, P. (2006). 16S rDNA-based analysis of dominant bacterial populations associated with early life stages of coho salmon (Oncorhynchus kisutch). Microb. Ecol. 51, 422-430. doi: 10.1007/s00248-0069037-9

Romero, J., Ringø, E., and Merrifield, D. L. (2014). “The gut microbiota of fish,” in Aquaculture Nutrition, eds D. Merrifield and E. Ringø (Chichester: John Wiley \& Sons), 75-100. doi: 10.1002/9781118897263.ch4

Rowland, I., Gibson, G., Heinken, A., Scott, K., Swann, J., Thiele, I., et al. (2018). Gut microbiota functions: metabolism of nutrients and other food components. Eur. J. Nutr. 57, 1-24. doi: 10.1007/s00394-017-1445-8

Saha, A. K., and Ray, A. K. (1998). Cellulase activity in rohu fingerlings. Aquac. Int. 6, 281-291. doi: 10.1023/A:1009210929594

Saha, S., Roy, R. N., Sen, S. K., and Ray, A. K. (2006). Characterization of cellulaseproducing bacteria from the digestive tract of tilapia, Oreochromis mossambica (Peters) and grass carp, Ctenopharyngodon idella (Valenciennes). Aquac. Res. 37, 380-388. doi: 10.1111/j.1365-2109.2006.01442.x

Samad, M. Y. A., Razak, C. N. A., Salleh, A. B., Zin, W., Yunus, W. M., Ampon, K., et al. (1989). A plate assay for primary screening of lipase activity. J. Microbiol. Methods 9, 51-56. doi: 10.1016/0167-7012(89)90030-4

Sarkar, S., Pramanik, A., Mitra, A., and Mukherjee, J. (2010). Bioprocessing data for the production of marine enzymes. Mar. Drugs 8, 1323-1372. doi: 10.3390/ md8041323

Sarrouh, B., Santos, T. M., Miyoshi, A., Dias, R., and Azevedo, V. (2012). Up-todate insight on industrial enzymes applications and global market. J. Bioprocess Biotechniq. S 4:2. doi: 10.1016/j.focat.2019.05.005

Sasmal, M., and Ray, R. R. (2015). Production of extracellular enzymes by the gut and gill microflora of Tilapia fish (Oreochromis niloticus). Asian J. Multidiscip. Stud. 3, 44-49.

Senghor, B., Sokhna, C., Ruimy, R., and Lagier, J.-C. (2018). Gut microbiota diversity according to dietary habits and geographical provenance. Hum. Microb. J. 8, 1-9. doi: 10.1016/j.humic.2018.01.001

Silva, S. K. H., and Widanapathirana, S. (1984). The nature of the aerobic gastrointestinal bacteria of cichlid fish Sarotherodon mossambicus (Peters) and Tilapia nilotica (Linnaeus) grown under captivity. J. Natl. Aquat. Resour. Agency 31, 73-79.

Sivakumar, K., Janani, D., and ShreeRama, M. (2015). Analysis of microbial biodiversity in intestine of ornamental fishes gut. Int. J. Fish. Aquat. Stud. 2, 232-234.

Sivaperumal, P., Kamala, K., and Rajaram, R. (2017). "Chapter Eight bioremediation of industrial waste through enzyme producing marine microorganisms," in Advances in Food and Nutrition Research Marine Enzymes Biotechnology: Production and Industrial Applications, Part III - Application of Marine Enzymes, eds S.-K. Kim and F. Toldrá (Cambridge, MA: Academic Press), 165-179. doi: 10.1016/bs.afnr.2016.10.006 
Soares, M. M., da Silva, R., and Gomes, E. (1999). Screening of bacterial strains for pectinolytic activity: characterization of the polygalacturonase produced by Bacillus sp. Rev. Microbiol. 30, 299-303. doi: 10.1590/s000137141999000400002

Sommer, F., and Bäckhed, F. (2013). The gut microbiota-masters of host development and physiology. Nat. Rev. Microbiol. 11, 227-238. doi: 10.1038/ nrmicro2974

Sugita, H., Kawasaki, J., and Deguchi, Y. (1997). Production of amylase by the intestinal microflora in cultured freshwater fish. Lett. Appl. Microbiol. 24, 105-108. doi: 10.1046/j.1472-765X.1997.00360.x

Sugita, H., Kawasaki, J., Kumazawa, J., and Deguchi, Y. (1996). Production of amylase by the intestinal bacteria of Japanese coastal animals. Lett. Appl. Microbiol. 23, 174-178. doi: 10.1111/j.1472-765X.1996.tb00058.x

Sumathi, C., Mohana, P. D., Dilli, B. V., and Sekaran, G. (2011). Analysis of enzyme activities of the gut bacterial communities in Labeo rohita fed differentially treated animal fleshing diets. J. Microb. Biochem. Technol. 3, 112-120.

Sun, Y.-Z., Yang, H.-L., Ma, R.-L., Song, K., and Lin, W.-Y. (2011). Molecular analysis of autochthonous microbiota along the digestive tract of juvenile grouper Epinephelus coioides following probiotic Bacillus pumilus administration. J. Appl. Microbiol. 110, 1093-1103. doi: 10.1111/j.1365-2672. 2011.04967.x

Sundara Raj, B. (1954). The problem of the apparent discontinuous distribution of Harpodon nehereus (Hamilton). Proceedings of the Indian Academy of Sciences Section B 40, 58-68. doi: 10.1007/BF03050402

Talwar, C., Nagar, S., Lal, R., and Negi, R. K. (2018). Fish gut microbiome: current approaches and future perspectives. Indian J. Microbiol. 58, 397-414. doi: 10. 1007/s12088-018-0760-y

Tiwari, O. N., Devi, T. B., Devi, K. S., Oinam, G., Indrama, T., Ojit, K., et al. (2015). Isolation and optimization of alkaline protease producing Bacteria from undisturbed soil of NE-region of India falling under Indo-Burma biodiversity hotspots -. J. Appl. Biol. Biotechnol. 3, 025-031.

Trincone, A. (2010). Potential biocatalysts originating from sea environments. J. Mol. Catal. B Enzym. 66, 241-256. doi: 10.1016/j.molcatb.2010.06.004

Trincone, A. (2011). Marine biocatalysts: enzymatic features and applications. Mar. Drugs 9, 478-499. doi: 10.3390/md9040478

Uhlig, H. (1998). Industrial Enzymes and Their Applications. Chichester: John Wiley \& Sons.

Vijayalaxmi, S., Anu Appaiah, K. A., Jayalakshmi, S. K., Mulimani, V. H., and Sreeramulu, K. (2013). Production of bioethanol from fermented sugars of sugarcane bagasse produced by lignocellulolytic enzymes of Exiguobacterium sp. VSG-1. Appl. Biochem. Biotechnol. 171, 246-260. doi: 10.1007/s12010-0130366-0

Waché, Y., Auffray, F., Gatesoupe, F.-J., Zambonino, J., Gayet, V., Labbé, L., et al. (2006). Cross effects of the strain of dietary Saccharomyces cerevisiae and rearing conditions on the onset of intestinal microbiota and digestive enzymes in rainbow trout, Onchorhynchus mykiss, fry. Aquaculture 258, 470-478. doi: 10.1016/j.aquaculture.2006.04.002

Wang, A. R., Ran, C., Ringø, E., and Zhou, Z. G. (2018). Progress in fish gastrointestinal microbiota research. Rev. Aquac. 10, 626-640. doi: 10.1111/raq. 12191

Wanka, K. M., Damerau, T., Costas, B., Krueger, A., Schulz, C., and Wuertz, S. (2018). Isolation and characterization of native probiotics for fish farming. BMC Microbiol. 18:119. doi: 10.1186/s12866-018-1260-2

Wu, F., Chen, B., Liu, S., Xia, X., Gao, L., Zhang, X., et al. (2020). Effects of woody forages on biodiversity and bioactivity of aerobic culturable gut bacteria of tilapia (Oreochromis niloticus). PLoS One 15:e0235560. doi: 10.1371/journal. pone. 0235560

Wu, S., Wang, G., Angert, E. R., Wang, W., Li, W., and Zou, H. (2012). Composition, diversity, and origin of the bacterial community in grass carp intestine. PLoS One 7:e30440. doi: 10.1371/journal.pone.00 30440

Yoon, S.-H., Ha, S.-M., Kwon, S., Lim, J., Kim, Y., Seo, H., et al. (2017). Introducing EzBioCloud: a taxonomically united database of $16 \mathrm{~S}$ rRNA gene sequences and whole-genome assemblies. Int. J. Syst. Evol. Microbiol. 67, 1613-1617. doi: 10.1099/ijsem.0.001755

Zhang, B., and Jin, X. (2014). Feeding habits and ontogenetic diet shifts of Bombay duck, Harpadon nehereus. Chin. J. Ocean. Limnol. 32, 542-548. doi: 10.1007/ s00343-014-3085-7

Zhang, C., and Kim, S.-K. (2010). Research and application of marine microbial enzymes: status and prospects. Mar. Drugs 8, 1920-1934. doi: 10.3390/ md8061920

Zhang, H., Audira, G., Li, Y., Xian, W., Varikkodan, M. M., and Hsiao, C.-D. (2017). Comparative study the expression of calcium cycling genes in Bombay duck (Harpadon nehereus) and beltfish (Trichiurus lepturus) with different swimming activities. Genomics Data 12, 58-61. doi: 10.1016/j.gdata.2017. 03.003

Conflict of Interest: The authors declare that the research was conducted in the absence of any commercial or financial relationships that could be construed as a potential conflict of interest.

Copyright (C) 2020 Hossain, Chowdhury, Mozumder, Chowdhury, Ali, Rahman and Dey. This is an open-access article distributed under the terms of the Creative Commons Attribution License (CC BY). The use, distribution or reproduction in other forums is permitted, provided the original author(s) and the copyright owner(s) are credited and that the original publication in this journal is cited, in accordance with accepted academic practice. No use, distribution or reproduction is permitted which does not comply with these terms. 